\title{
IDENTIFIKASI DAMPAK PERUBAHAN FUNGSI EKOSISTEM PESISIR TERHADAP LINGKUNGAN DI WILAYAH PESISIR KECAMATAN MUARAGEMBONG
}

\author{
${ }^{1}$ YULIA ASYIAWATI DAN ${ }^{2}$ LELY SYIDDATUL AKLIYAH \\ 1)2)Dosen Program Studi Perencanaan Wilayah dan Kota, Fakultas Teknik, Universitas Islam Bandung \\ E-mail : yulia_asyiawati@yahoo.com dan E-mail : ulil_sa@yahoo.com
}

\begin{abstract}
ABSTRAK
Perubahan yang terjadi pada wilayah pesisir dan laut tidak hanya sekedar gejala alam semata, tetapi kondisi ini sangat besar dipengaruhi oleh aktifitas manusia yang ada di sekitarnya. Wilayah pesisir merupakan wilayah penerima tekanan lebih besar dibandingkan dengan wilayah lain, karena wilayah pesisir mempunyai fungsi sebagai penyedia sumberdaya alam, penyedia jasa-jasa pendukung kehidupan, penyedia jasa kenyamanan dan sebagai penerima limbah dari aktivitas pembangunan yang terdapat di lahan atas (lahan daratan) seperti kegiatan permukiman aktivitas perdagangan, perikanan dan kegiatan industri. Semua dari kegiatan tersebut memberikan dampak terhadap wilayah pesisir yang dapat mempengaruhi pada kualitas lingkungan wilayah pesisir terutama pada penurunan kualitas ekosistem pesisir.

Wilayah Pesisir Muaragembong dimanfaatkan sebagai multiuse, mengakibatkan ketidakteraturan dalam pemanfaatan kawasan sehingga menimbulkan perubahan fungsi dari ekosistem pesisir yang mengakibatkan penurunan terhadap kualitas ekosistem dan lingkungan. Hal ini mengakibatkan terjadinya kerusakan lingkungan di wilayah pesisir Kecamatan Muaragembong. Berdasarkan kondisi yang ada, maka artikel ini bertujuan untuk mengidentifikasi dampak perubahan fungsi ekosistem pesisir terhadap lingkungan di wilayah pesisir khusnya yang menjadi lokus kajian di wilayah pesisir Kecamatan muaragembong. Hal ini diharapkan dapat memberikan gambaran tentang identifikasi dampak yang ditimbulkan dari perubahan fungsi ekosistem pesisir di Wilayah Pesisir Muaragembong, sehingga dapat memberikan masukan untuk merencanakan wilayah secara berkelanjutan.
\end{abstract}

Keywords: ekosistem pesisir, mangrove, estuaria, wilayah pesisir, berkelanjutan

\section{PENDAHULUAN}

Wilayah pesisir mempunyai peranan penting untuk kesejahteraan hidup masyarakat, khususnya bagi masyarakat di wilayah pesisir. Wilayah pesisir merupakan wilayah yang terletak antara wilayah daratan dan wilayah lautan, yang menyediakan sumberdaya alam untuk memenuhi kebutuhan hidup masyarakat. Wilayah pesisir mempunyai fungsi sebagai penyedia sumberdaya alam, penyedia jasa-jasa pendukung kehidupan, penyedia jasa kenyamanan dan sebagai penerima limbah dari aktivitas pembangunan yang terdapat di lahan atas (lahan daratan) seperti kegiatan permukiman aktivitas perdagangan, perikanan dan kegiatan industri. Sumberdaya alam yang terdapat di wilayah pesisir adalah ekosistem estuaria, ekosistem mangrove, ekosistem terumbu karang, ekosistem padang lamun dan ekosistem pulau-pulau kecil; yang mempunyai fungsi ekologis dan ekonomis untuk keberlanjutan dari wilayah pesisir di masa yang akan datang.

Kecamatan Muaragembong merupakan salah satu wilayah pesisir yang mempunyai ekosistem estuaria dan ekosistem mangrove untuk mendukung kehidupan masyarakat. Kedua ekosistem ini mempunyai peran yang sangat penting dalam mendukung kehidupan masyarakat di Wilayah Pesisir 
Muaragembong, disamping itu juga kedua ekosistem mempunyai fungsi ekologis dalam menjaga keseimbangan lingkungan wilayah pesisir.

Ekosistem estuari merupakan perairan yang semi tertutup yang berhubungan bebas dengan laut, sehingga air laut dengan salinitas tinggi dapat bercampur dengan air tawar (Pickard, 1967). Oleh karena itu ekosistem estuaria mempunyai fungsi ekonomi dan fungsi ekologis. Secara ekonomi, dapat dimanfaatkan sebagai tempat permukiman, sebagai tempat pengembangan kegiatan perikanan tangkap dan perikanan budidaya (Bengen, 2004). Di sisi lain dijelaskan bahwa fungsi ekologis dari ekosistem estuaria adalah sebagai sumber zat hara dan bahan organik yang diangkut lewat sirkulasi pasang surut (tidal circulation), penyedia habitat bagi sejumlah spesies hewan yang bergantung pada estuaria sebagai tempat berlindung dan tempat mencari makanan (feeding ground) dan sebagai tempat untuk bereproduksi dan/atau tempat tumbuh besar (nursery ground) terutama bagi sejumlah spesies ikan dan udang. sebagai sumner zat hara.

Ekosistem mangrove merupakan suatu tipe hutan yang tumbuh di daerah pasang surut (terutama di pantai yang terlindung, laguna, muara sungai) yang tergenang waktu air laut pasang dan bebas dari genangan pada saat air laut surut, yang komunitas tumbuhannya toleran terhadap garam (Kusmana et . all., 2005). Dengan demikian ekosistem mangrove mempunyai fungsi ekologis dan ekonomi. Fungsi ekologis dari ekosistem mangrove sebagai pelindung pantai dari abrasi, pengendali banjir, tempat hidup biota laut untuk berlindung, mencari makan, pemijahan maupun pengasuhan, sebagai sumber makanan bgi spesies-spesies yang ada, penambat zat beracun, penyerap karbon, Disamping itu fungsi ekonomi dari ekosistem mangrove adalah ekosistem mangrove dapat dimanfaaatkan untuk penghasil bahan obat-obatan, sebagai penghasil bahan pangan seperti ikan, udang, kerang kepiting, serta sebagai tempat rekreasi dan wisata.
Sejalan dengan fungsi dari ekosistem pesisir tersebut, di Wilayah Pesisir Muaragembong pada saat ini dimanfaatkan untuk kegiatan permukiman, perikanan budidaya, perikanan tangkap, pertanian, perdagangan, jasa dan pemerintahan serta perhubungan. Semua kegiatan yang terdapat di Wilayah Pesisir Muaragembong berkembang sejalan dengan perkembangan jumlah penduduk wilayah, yang mempengaruhi terhadap ekosistem pesisir, sehingga mengakibatkan penurunan kualitas kondisi ekosistem pesisir. Penurunan kualitas ekosistem di Wilayah Pesisir Muaragembong mempengaruhi kepada kulaitas lingkungan. Hal ini dapat dilihat dari kondisi lingkungan di Wilayah Pesisir Muaragembong. Kondisi lingkungan di Wilayah Pesisir Muaragembong saat ini adalah terjadinya abrasi, banjir dan sanitasi lingkungan yang kurang baik.

Berdasarkan pada fenomena yang di atas, artikel ini mencoba membahas dan mengidentifikasi kondisi lingkungan di Wilayah Pesisir Muaragembong sejalan dengan perubahan fungsi ekosistem pesisir untuk memenuhi kehidupan masyarakat pesisir. Hasil dari identifikasi ini diharapkan dapat menjadi masukan dalam melakukan penilaian wilayah pesisir Muaragembong untuk pengembangan wilayah di masa yang akan datang, sehingga dapat mewujudkan masyarakat yang sejahtera dan lingkungan yang lestari.

\section{KAJIAN LITERATUR}

\section{Pengertian Wilayah Pesisir}

Wilayah pesisir atau coastal zone adalah wilayah yang unik, karena dalam konteks bentang alam, wilayah pesisir merupakan tempat bertemunya daratan dan lautan (Kay dan Alder 1999 dalam Asyiawati, 2010). Sorensen dan McCreary (1990) dalam Asyiawati (2010) mendefinisikan wilayah pesisir merupakan tempat bertemunya daratan dan lautan yang didefinisikan sebagai daerah interface atau daerah transisi dimana segala macam proses yang terjadi tergantung dari interaksi yang sangat intens dari daratan 
dan lautan. Dengan demikian, wilayah pesisir meliputi suatu kawasan peralihan antara ekosistem dan daratan yang sempit, dengan garis rata-rata pasang tertinggi sampai 200 meter ke arah darat dan ke arah laut meliputi garis pantai pada saat rata-rata pasang terendah. Secara ekologis wilayah pesisir adalah suatu wilayah peralihan antara ekosistem darat dan laut. Batas wilayah pesisir ke arah darat mencakup daratan yang masih dipengaruhi oleh proses-proses kelautan (seperti pasang surut, percikan air gelombang, intrusi air laut dan angin laut), sedangkan batas wilayah pesisir ke arah laut meliputi perairan laut yang masih dipengaruhi oleh proses-proses alamiah dan kegiatan manusia di daratan, termasuk air sungai dan aliran air permukaan (run off), sedimentasi, pencemaran dan antara lain yang merupakan penghubung (channels) bagi dampak yang dihasilkan dari kegiatan manusia di daratan ke lingkungan laut. Pada dasarnya pemahaman tentang pengertian wilayah pesisir sangat beragam dan berbeda antara satu dengan yang lainnya. Perbedaan pengertian wilayah pesisir ini bergantung pada penentuan batas definitif dari wilayah pesisir baik ke arah darat maupun ke arah laut.

Dahuri et al. (1996) menjelaskan bahwa wilayah pesisir merupakan suatu wilayah peralihan antara daratan dan lautan, dimana batas wilayah pesisir ke arah darat adalah jarak arbitrer dari rata-rata pasang tertinggi (mean high tide) dan batas ke arah laut adalah batas yuridiksi wilayah atau negara. Definisi lain menerangkan bahwa wilayah pesisir merupakan suatu sistem yang terdiri dari beberapa sumberdaya yaitu sumberdaya manusia, sumberdaya alam, sumberdaya buatan maupun sumberdaya dana yang merupakan satu kesatuan dan saling berinteraksi antara satu dengan yang lainnya. Secara umum wilayah pesisir merupakan kawasan yang mempunyai sumberdaya alam yang potensial untuk dikembangkan, sehingga secara ekonomi dapat meningkatkan pendapatan masyarakat. Oleh karena itu, dalam pengelolaan wilayah pesisir perlu memperhatikan keterpaduan dan keberlanjutan agar sumberdaya yang ada (terutama sumberdaya yang tidak dapat pulih), tidak punah dan tidak terjadi degradasi sumberdaya.

Dalam Pasal 1 UU No. 27 tahun 2007 tentang Pengelolaan Wilayah Pesisir dan Pulau-Pulau Kecil (Anonim 2007c) dijelaskan bahwa wilayah pesisir merupakan daerah peralihan antara ekosisten darat dan laut yang dipengaruhi oleh perubahan di darat dan laut, yang mempunyai keanekaragaman sumberdaya pesisir. Sumberdaya pesisir tersebut terdiri dari sumberdaya hayati (meliputi ikan, terumbu karang, padang lamun, mangrove dan biota laut lainnya); sumberdaya nonhayati (meliputi pasir, air laut, mineral dasar laut); sumberdaya buatan (meliputi infrastruktur laut yang terkait dengan kelautan dan perikanan); dan jasa-jasa lingkungan (berupa keindahan alam, permukaan dasar laut, tempat instalasi bawah air yang terkait dengan kelautan dan perikanan serta energi gelombang laut yang terdapat di wilayah pesisir). Wilayah pesisir mempunyai tiga karakteristik, yaitu : 1) Merupakan wilayah pertemuan antara berbagai aspek yang ada di darat, laut dan udara, yang merupakan bentuk dari hasil keseimbangan dinamis suatu penghancuran dan pembangunan dari ketiga unsur tersebut; 2) Berfungsi sebagai zona penyangga (buffer zone) dan habitat dari berbagai jenis sumberdaya hayati; 3) Memiliki tingkat kesuburan yang tinggi karena merupakan sumber zat organik yang penting dalam rantai makanan laut.

Wilayah pesisir terdiri dari bermacammacam aktivitas manusia yang mempengaruhi wilayah pesisir secara langsung dan tidak langsung, baik di lingkungan daratan maupun lingkungan perairan (Chua 2006). Dari pengertian ini dapat disimpulkan bahwa wilayah pesisir itu merupakan suatu sistem yang terdiri dari sub sistem lingkungan daratan dan lingkungan perairan serta aktivitas manusia baik aktivitas sosial maupun ekonomi. Secara diagramatis dapat dideskripsikan seperti Gambar 1. 


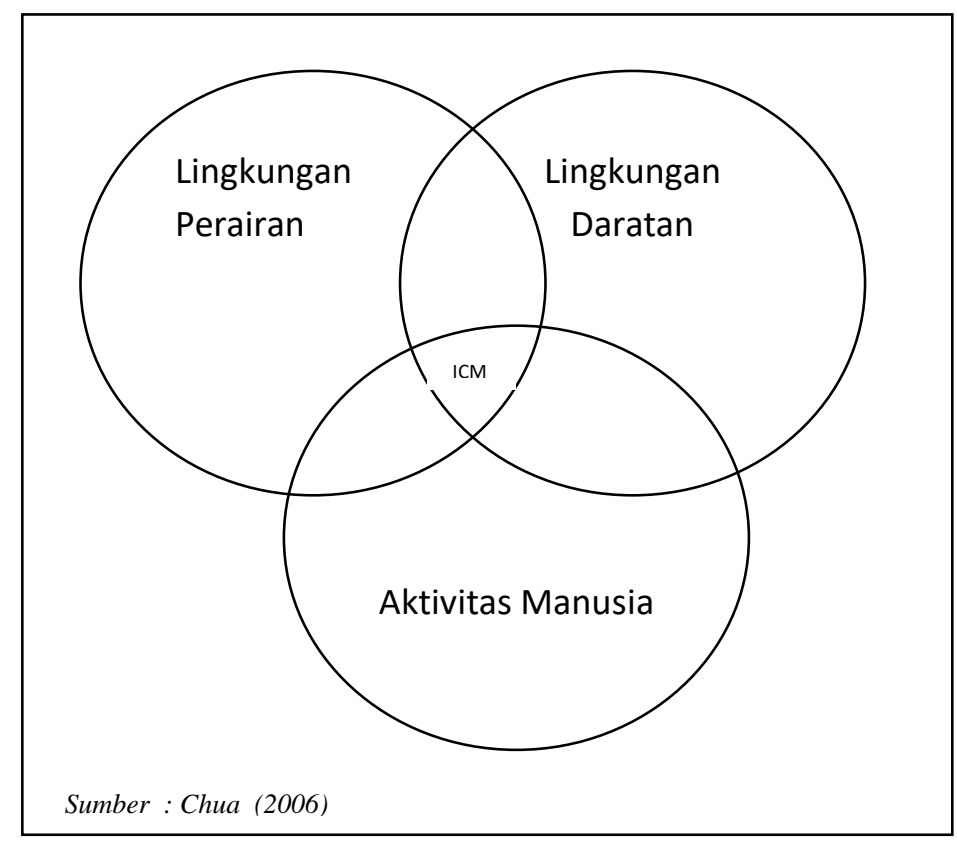

Gambar 1 Sistem Wilayah Pesisir

Dari Gambar 1 dapat disimpulkan bahwa wilayah pesisir merupakan suatu sistem pesisir dimana pada wilayah pesisir terdapat berbagai komponen yang mengisi ruang wilayah (permukiman, sumberdaya manusia beserta kegiatannya, sumberdaya alam, sarana dan prasarana) yang saling berinteraksi dalam suatu bentuk saling ketergantungan yang teratur untuk mencapai tujuan. Tujuan dari interaksi antar subsistem yang terdapat dalam sistem wilayah pesisir adalah pengelolaan wilayah pesisir secara terpadu untuk mewujudkan keserasian dan keseimbangan lingkungan pesisir di masa yang akan datang.

\section{Ekosistem Estuaria}

Estuaria didefinisikan sebagai perairan yang semi tertutup yang berhubungan bebas dengan laut, sehingga laut dengan salinitas tinggi dapat bercampur dengan air tawar (Bengen; 2002). Wilayah ini meliputi muara sungai dan delta-delta besar, hutan mangrove dekat estuari dan hamparan lumpur dan pasir yang luas. Wilayah ini juga dapat dikatakan sebagai wilayah yang sangat dinamis. Karena selalu terjadi proses dan perubahan baik lingkungan fisik maupun biologis. Sehingga estuari memiliki sifat yang unik akibat adanya percampuran antara massa air laut dan air tawar membuat tingkat salinitas yang dimiliki dapat berubah-ubah dan sangat fluktuatif. Berubahnya salinitas estuari dapat dipengaruhi oleh adanya pasang surut air dan musim. Selama musim kemarau, volume air sungai yang masuk berkurang, sehingga air laut dapat masuk sampai ke daerah yang lebih tinggi atau hulu dan menyebabkan salinitas yang dimiliki wilayah estuari meningkat. Sebaliknya yang terjadi apabila pada musim penghujan air tawar yang masuk dari hulu ke wilayah estuari meningkat sehingga salinitas yang dimiliki rendah (Barus, 2002).

Adanya aliran air tawar yang terjadi terus menerus dari hulu sungai dan adanya proses gerakan air akibat arus pasang surut yang mengangkut mineral-mineral, bahan organik dan sedimen merupakan bahan dasar yang dapat menunjang produktifitas perairan di wilayah estuari yang melebihi produktifitas laut lepas dan perairan air tawar. Oleh karena itu, lingkungan wilayah estuari menjadi paling produktif. Dengan kata lain dapat juga dijelaskan bahwa estuaria adalah sebagai berikut :

Pertama, Tempat bertemunya arus air dengan arus pasang-surut, yang berlawanan 
menyebabkan suatu pengaruh yang kuat pada sedimentasi, pencampuran air dan ciri-ciri fisika lainnya, serta membawa pengaruh besar pada biotanya.

Kedua, Pencampuran kedua macam air tersebut menghasilkan suatu sifat fisika lingkungan khusus yang tidak sama dengan sifat air sungai maupun air laut.

Ketiga, Perubahan yang terjadi akibat adanya pasang-surut mengharuskan komunitas mengadakan penyesuaian secara fisiologis dengan lingkungan sekelilingnya.

Keempat, Tingkat kadar garam di daerah estuaria tergantung pada pasang-surut air laut, banyaknya aliran air tawar dan arus-arus lainnya, serta topografi daerah estuaria tersebut.

Oleh karena estuaria ini meruakan kawasan yang snagat dinamis, sehingga ekosistem estuaria merupakan ekosistem yang produktif. Produktivitas hayatinya setaraf dengan prokduktivitas hayati hutan hujan tropik dan ekosistem terumbu karang. Produktivitas hayati estuaria lebih tinggi dibandingkan dengan produktivitas hayati perairan laut dan perairan tawar. Hal ini salah satunya disebabkan oleh fungsi dari estuaria yang merupakan perangkap zat hara dan bahan organik yang berasal dari perairan disekitarnya terutama. Zat-zat yang terperangkap tersebut akan mengalami suatu siklus yang disebut dengan siklus nutrient yang keberadaannya dipengaruhi oleh musim, kondisi muara (Flynn, 2008), pasang surut, debit air tawar dan angin (Arndt dkk., 2011). Dengan demikian estuaria mempunyai fungsi ekologi sebagai berikut :

Pertama, Merupakan sumber zat hara dan bahan organik bagi bagian estuari yang jauh dari garis pantai maupun yang berdekatan denganya lewat sirkulasi pasang surut (tidal circulation).

Kedua, Menyediakan habitat bagi sejumlah spesies ikan yang ekonomis penting sebagai tempat berlindung dan tempat mencari makan (feeding ground).

Ketiga, Memenuhi kebutuhan bermacam spesies ikan dan udang yang hidup dilepas pantai, tetapi bermigrasi keperairan dangkal dan berlindung untuk memproduksi dan/atau sebagai tempat tumbuh besar (nursery ground) anak mereka.

Selain estuaria mempunyai fungsi ekologis, estuaria juga dapat dimanfaatkan oleh manusia untuk beberapa kegiatan sebagai berikut : 1) Sebagai tempat pemukiman; 2) Sebagai tempat penangkapan dan budidaya sumberdaya ikan; 3) Sebagai jalur transportasi; 4) Sebagai pelabuhan dan kawasan industri.

\section{Ekosistem Mangrove}

Hutan mangrove merupakan hutan hujan yang terdapat di sepanjang garis pantai perairan tropis sampai sub-tropis dan mempunyai ciri-ciri tersendiri dengan kekhasan biota yang hidup disana. Ekosistem mangrove merupakan ekosistem yang lebih spesifik jika dibandingkan dengan ekosistem lainnya karena mempunyai vegetasi yang agak seragam, serta mempunyai tajuk yang rata, tidak mempunyai lapisan tajuk dengan bentukan yang khas (Bengen 2004).

Sebagai suatu ekosistem khas wilayah pesisir, hutan mangrove memiliki beberapa fungsi ekologis penting yaitu: (Bengen 2004)

Pertama, Sebagai peredam gelombang dan angin badai, pelindung pantai dari abrasi, penahan lumpur dan perangkap sedimen yang diangkut oleh aliran air permukaan.

Kedua, Sebagai penghasil sejumlah besar detritus, terutama yang berasal dari daun dan dahan pohon mangrove yang rontok. Sebagian dari detritus ini dapat dimanfaatkan sebagai bahan makanan bagi para pemakan detritus, dan sebagian lagi diuraikan secara bakterial menjadi mineralmineral hara yang berperan dalam penyuburan perairan.

Ketiga, Sebagai daerah asuhan (nursery ground), daerah mencari makanan (feeding ground) dan daerah pemijahan (spawning ground) bermacam biota perairan (ikan, udang dan kerang-kerangan) baik yang hidup di perairan pantai maupun lepas pantai.

Muhdhar (2003) menjelaskan bahwa hutan mangrove merupakan ekosistem hutan yang unik, terdapat di daerah pasang surut sepanjang pantai atau muara sungai, membentuk sumberdaya alam yang 
mempunyai nilai ekonomi dan nilai ekologi tinggi, tetapi rentan terhadap kerusakan bila kurang bijaksana dalam pengelolaannya. Oleh karena itu, fungsi ekonomis hutan mangrove adalah sebagai cadangan sumber alam (bahan mentah) untuk dapat diolah menjadi komoditi perdagangan yang bisa menambah kesejahteraan penduduk setempat. Pemanfaatan tersebut tetap harus mengacu kepada kepentingan keseimbangan/kelestarian daya dukung lingkungan hutan mangrove. Oleh sebab itu pemanfaatan yang tanpa merusak sangat dianjurkan antara lain: upaya peternakan (pembesaran) kepiting di lingkungan hutan mangrove, produksi madu dari hutan mangrove bisa langsung dimanfaatkan sebagai komoditi, tempat peternakan kerangkerangan, jenis mangrove seperti Sonneratia caseolaris sp. mempunyai potensi sebagai bahan obat maupun pangan. Hutan mangrove juga dapat dijadikan sebagai tempat pariwisata.

Bengen (2004) menjelaskan, ekosistem mangrove mempunyai manfaat langsung dan manfaat tidak langsung bagi kehidupan manusia. Manfaat langsung dari ekosistem mangrove adalah untuk kayu bakar, bahan konstruksi bangunan, bahan untuk membuat arang, serta dapat juga dibuat untuk bubur kertas, sedangkan manfaat tidak langsung dari ekosistem mangrove adalah pengembangan kegiatan wisata-mangrove. Oleh karena itu, keberadaan dari ekosistem mangrove pada wilayah pesisir, disamping berfungsi sebagai kawasan penyangga, juga mempunyai nilai ekonomi tinggi.

\section{METODOLOGI PENELITIAN}

\section{$\underline{\text { Lokasi Studi }}$}

Lokasi pengamatan dalam melakukan identifikasi perubahan ekosistem pesisir terhadap lingkungan di Wilayah Pesisir Muaraga gembong, secara geografis berada pada posisi $6^{\circ} 00^{\prime}-6^{\circ} 05^{\prime}$ Lintang Selatan dan $106^{\circ} 57^{\prime}-107^{\circ} 02^{\prime}$ Bujur Timur dan merupakan Kecamtan Muaragembong secara administrasi. Kecamatan Muaragembong merupakan salah satu kecamatan yang terdapat di bagian Utara Kabupaten Bekasi yang mempunyai wilayah sebesar 122,90 $\mathrm{Km}^{2}$. Kecamatan Muaragembong mempunyai batas administrasi sebagai berikut (Lihat Gambar 2) :

\begin{tabular}{|c|c|c|}
\hline Sebelah Utara & \multicolumn{2}{|c|}{ : Laut Jawa } \\
\hline Sebelah Selatan & & Kecamatan \\
\hline $\begin{array}{l}\text { Cabangbungin } \\
\text { Sukawangi }\end{array}$ & dan & Kecamatan \\
\hline $\begin{array}{r}\text { Sebelah Timur } \\
\text { Karawang }\end{array}$ & & Kabupaten \\
\hline Sebelah Barat & & \\
\hline
\end{tabular}




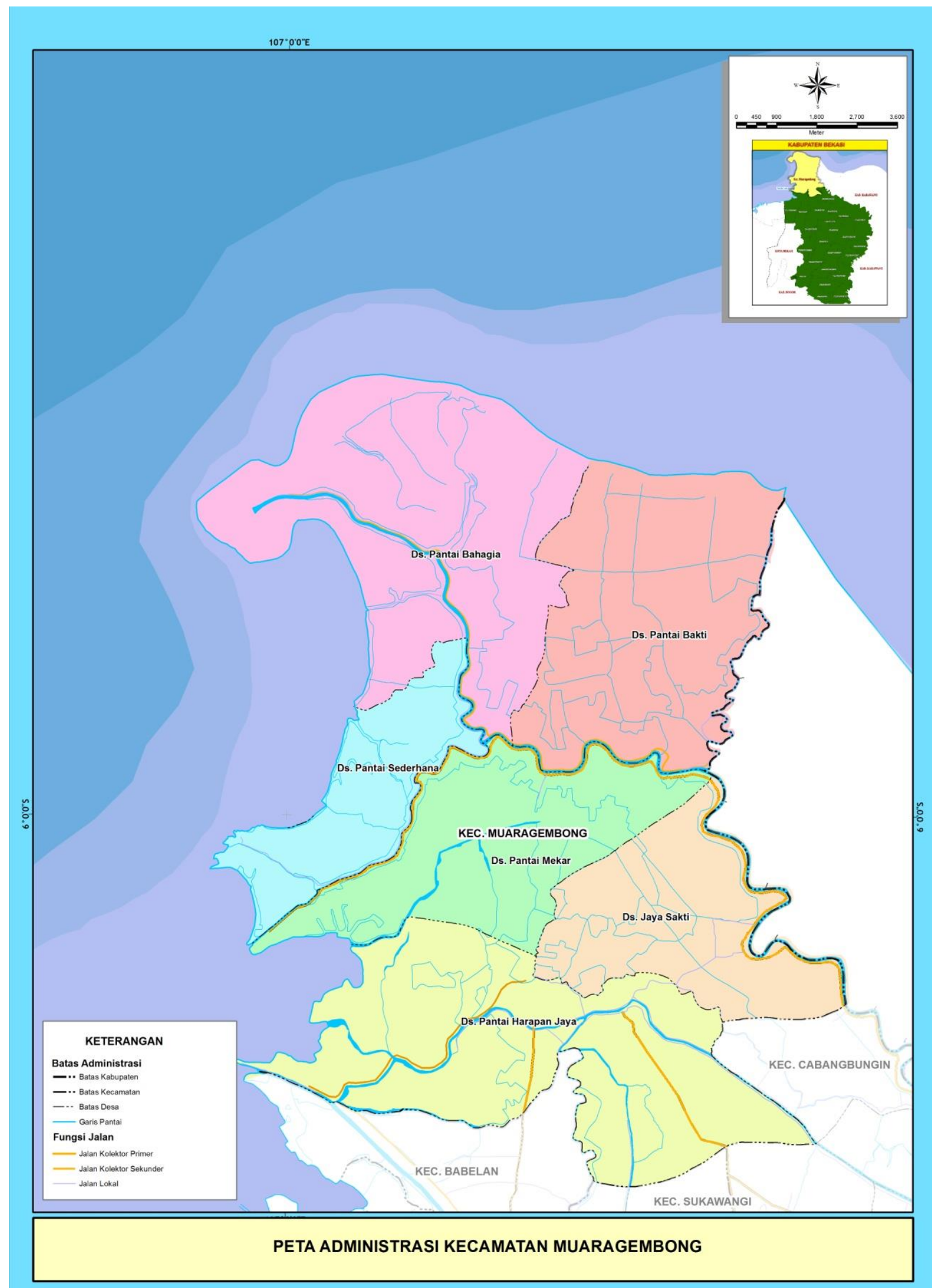

Gambar 2 Peta Administrasi Wilayah Pesisir Muaragembong Sumber : RTRW Kabupaten Bekasi 2009 - 2029 


\section{Metodologi}

Metode pengumpulan data yang dilakukan dalam mengidentifikasi perubahan fungsi ekosistem pesisir terhadap lingkungan di Wilayah Pesisir Muaragembong adalah dengan menggunakan metode survey groundcheck dan metode wawancara secara tidak terstruktur yang dilakukan dengan masyarakat pesisir Muaragembong. Metode analisis yang dilakukan dalam mengidentifikasi perubahan fungsi ekosistem pesisir terhadap lingkungan di Wilayah Pesisir Muaragembong adalah dengan menggunakan metode tumpang tindih (overlay). Variavel yang dijadikan indikator dalam melakukan identifikasi perubahan ekosistem pesisir adalah perubahan luasan dari ekosistem pesisir, kegiatan ekonomi masyarakat, dan perubahan kondisi lingkungan wilayah pesisir.

HASIL DAN PEMBAHASAN

\section{Karakteristik Wilayah Pesisir}

\section{Muaragembong}

Wilayah Pesisir Muaragembong yang mempunyai luas sebesar $122,90 \mathrm{Km}^{2}$, terdiri dari 6 (enam) desa yaitu Desa Pantai Bahagia, Pantai Bakti, Pantai Sederhana,
Pantai Mekar, Pantai Jaya Sakti, dan Desa Pantai Harapan Jaya. Dari ke-enam desa tersebut didiami oleh penduduk sebesar 37.358 jiwa (Kecamatan Muaragembong Dalam Angka, Tahun 2011) yang tersebar di seluruh bagian wilayah. Pola penggunaan lahan di Wiayah pesisir Muaragembong pada umumnya didominasi oleh hutan lindung, disamping ada juga untuk penggunaan yang lain seperti permukiman, industri, pariwisata dan pertanian (lihat Gambar 3).

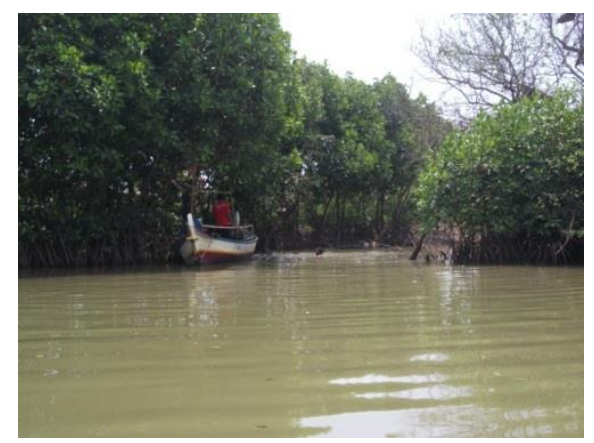

Wilayah Pesisir Muaragembong yang dilewati dan sekaligus merupakan muara Sungai Citarum dengan 4 (empat) anak sungai yang langsung bermuara ke Laut Jawa yang disebut Muara Bendera yang terdapat di Desa Pantai Bahagia. Wilayah Pesisir Muaragembong mempunyai ekosistem estuari dan ekosistem mangrove. 


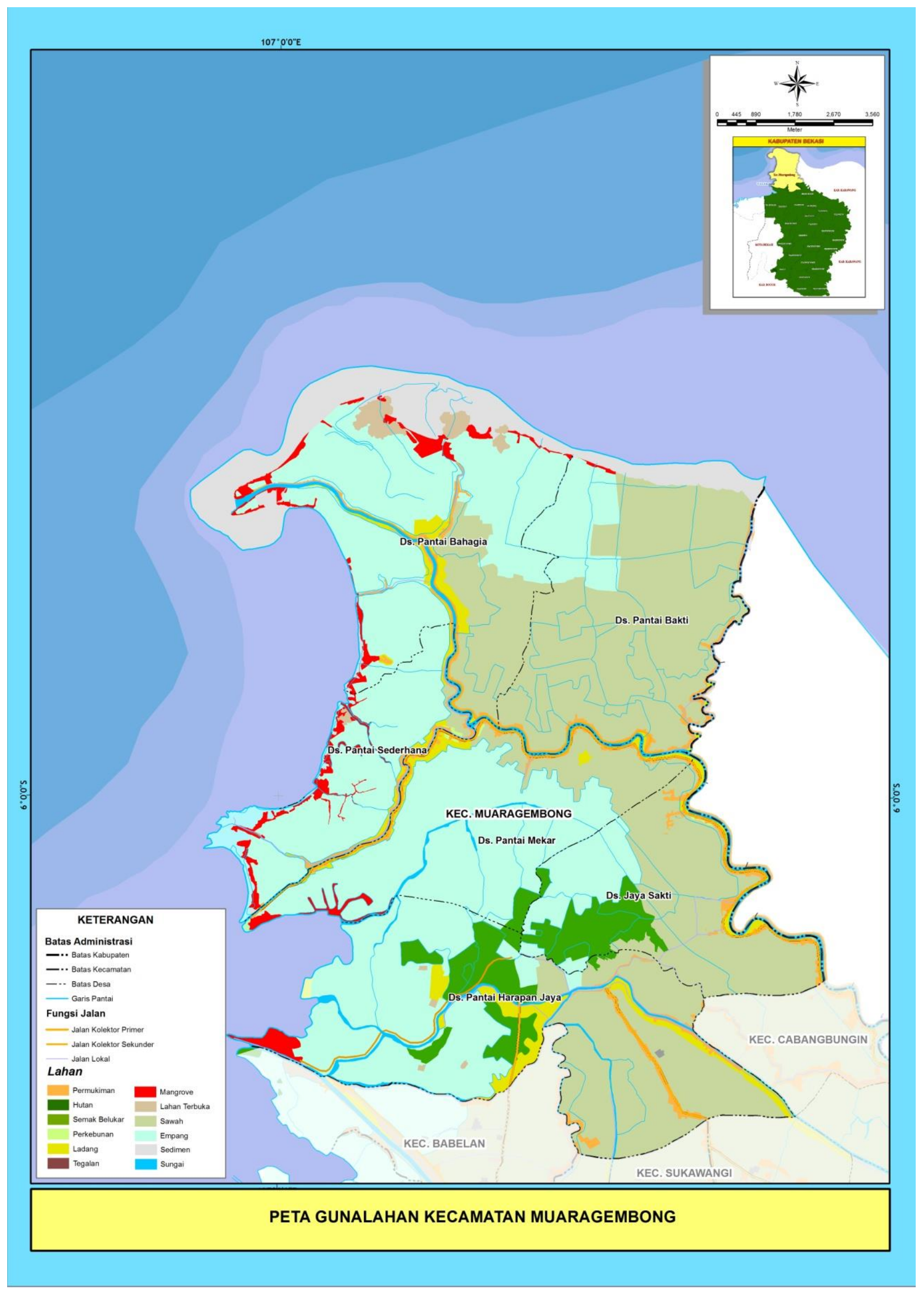

Gambar 2 Peta Penggunaan Lahan

Sumber : RTRW Kabupaten Bekasi 2009 - 2029 dan Hasil Groundcheck Tahun 2012 
Berdasarkan penelitian yang dilakukan oleh Handayani tahun 2006 diperoleh hasil bahwa luas ekosistem mangrove mengalami penurunan sebesar 6,74\% (data tahun 1992 dan data tahun 2002). Sedangkan berdasarkan data pada tahun 2012 bahwa luas ekosistem mangrove di Wilayah pesisir Muaragembong adalah 822,24 ha, hal ini menunjukkan penurunan luas ekosistem mangrove sebesar $5,06 \%$ dibandingkan dengan data luas ekosistem mangrove pada tahun 2002. Perubahan peruntukan dari ekosistem mangrove ini didominasi diperuntukkan untuk kegiatan budidaya perikanan (tambak). Hal ini dapat dilihat dari perubahan luas kawasan tambak yang menunjukkan penambahan luas tambak sebesar 4,55\% (data tahun 1992 dan data tahun 2002). Sedangkan berdasarkan data tahun 2012 terjadi penambahan luas kawasan tambak sebesar 723,253 ha dari luas tambak tahun 2002 atau terjadi penambahan luas sebesar 17,60\% (data tahun 2002 dan data tahun 2012). Sedangkan luas permukiman bertambah menjadi 3003,88 ha tahun 2001, dimana terjadi penambahan luas sebesar $707,40 \%$ dari luas permukiman pada tahun 2002 sebesar 372,043 ha. Hal ini menunjukkan bahwa terjadi pergeseran peenggunaan dari lahan hutan mangrove berubah menjadi lahan tambak dan lahan permukiman.

Ekosistem mangrove yang terdapat di Wilayah Pesisir Muaragembong banyak terdapat di sepanjang garis pantai dan sepanjang estuari. Ekosistem mangrove di Wilayah mempunyai 23 jenis yang didominasi oleh jenis Api-api (Avicennia spp.), Bakau (Rhizophora spp.), Pedada (Sonneratia caseolaris). Sedangkan hutan mangrove ikutan terdiri dari 13 jenis yang didominasi oleh Bintan (Cerbera odollam), Kiser (Fimbristylis verruginea) dan Ketapang (Terminalia catappa). Adapun jenis tumbuhan di muara air tawar terdiri dari 11 jenis yang didominasi oleh Kiser (Fimbristylis verruginea) dan Nipah (Nypha fruticans).

Kondisi ekosistem mangrove yang terdapat di Wilayah Pesisir Muaragembong saat ini sudah mulai mengalami kerusakan. Hal ini disebabkan oleh pembukaan lahan untuk pengembangan kegiatan perikanan budidaya (tambak) dan kegiatan permukiman yang dilakukan oleh stakeholders (penduduk) yang berada di wilayah Pesisir Muaragembong. Lahan yang dibuka untuk kegiatan perikanan budidaya (tambak) dan permukiman adalah lahan yang berada pada ekosistem mangrove dan estuari, sehingga hal ini mengakibatkan terganggunya keseimbangan ekosistem dan lingkungan di Wilayah Pesisir Muaragembong.

Oleh karena Wilayah Pesisir Muaragembong merupakan wilayah peralihan antara wilayah daratan dan wilayah lautan, kegiatan ekonomi masyarakat yang berkembang adalah kegiatan perikanan budidaya, perikanan tangkap, pertanian dan perdagangan. Hal ini dapat dilihat dari struktur mata pencaharian penduduk di Wilayah Pesisir Muaragembong, dimana penduduk yang mempunyai mata pencaharian sebagai petani tambak dan nelayan adalah sebesar $49,85 \%$ dari jumlah penduduk wilayah. Sedangkan mata pencaharian lain yang diusahakan oleh penduduk wilayah Muaragembong dalam memenuhi kehidupan adalah sebagai petani, pedagang, buruh industri, jasa angkutan, karyawan/pensiunan, serta sebagai wiraswasta. Produksi kegiatan perikanan yang diusahakan oleh masyarakat Wilayah Pesisir Muaragembong berupa ikan belanak, bandeng, udang, kerang hijau dan jenis komoditi perikana budidaya yang lainnya (lihat Tabel 1). 


\section{Tabel 1 Produksi Budidaya Ikan di Kecamatan Muaragembong Tahun 2011 No Jenis Perikanan Komoditi Produksi (Ton) Budidaya}

\begin{tabular}{|c|c|c|c|}
\hline \multirow{5}{*}{ I } & \multirow{4}{*}{ Kolam } & Lele & 6 \\
\hline & & Nila & 2,66 \\
\hline & & Bawal & 0,13 \\
\hline & & Gurame & - \\
\hline & Total & & 8,79 \\
\hline \multirow{7}{*}{ II } & \multirow{5}{*}{ Tambak } & Belanak & 170,78 \\
\hline & & Bandeng & 5637,17 \\
\hline & & Udang & 1477,31 \\
\hline & & Rumput Laut & 11687,79 \\
\hline & & Mujair & 687,05 \\
\hline & Total & & 19660,10 \\
\hline & Kerang hijau & & 58,81 \\
\hline
\end{tabular}

Disamping kegiatan perikanan, kegiatan ekonomi yang dilakukan oleh masyarakat Wilayah Pesisisr Muaragembong adalah sebagai penyedia jasa transportasi. Transportasi yang ada di Wiayah Muaragembong lebih terfokus kepada transportasi laut dan sungai karena transportasi darat tidak mendukung kegiatan yang ada di Muaragembong. Faktor jaringan jalan yang menjadi kendala transportasi darat yang ada di Muaragembong tidak terkonsentrasi dengan baik sehingga banyak

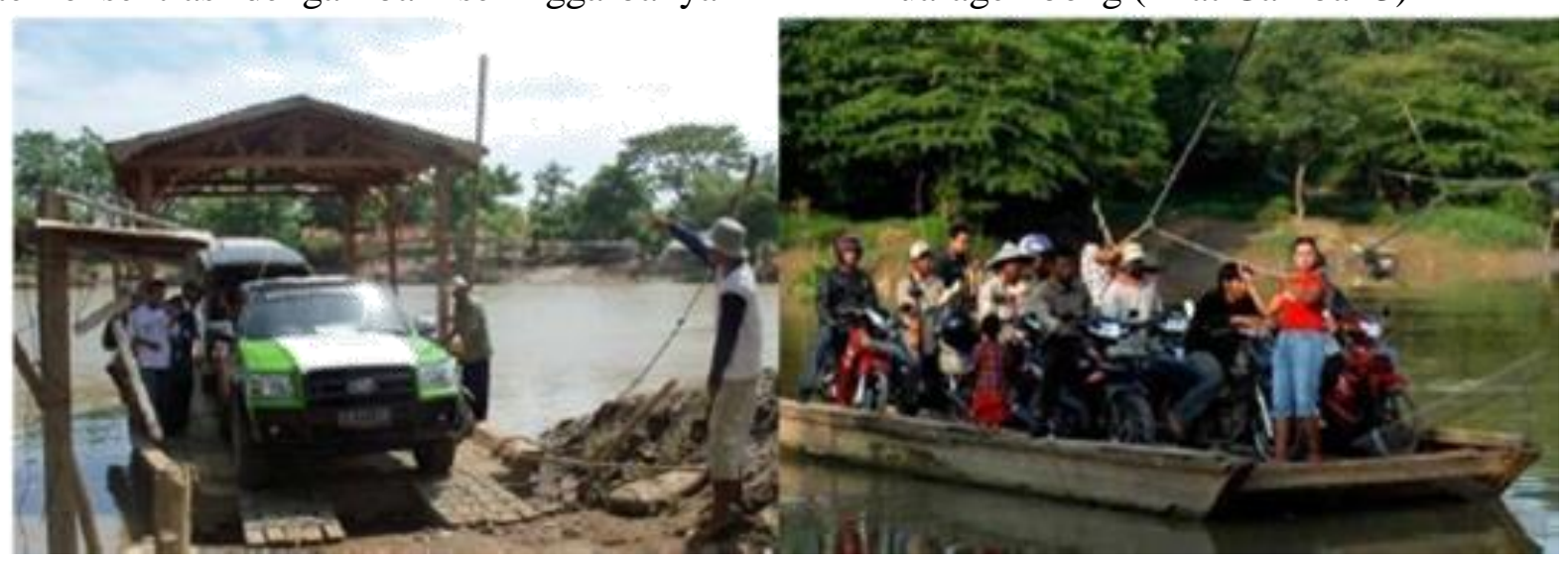

Gambar 3 Kondisi Transportasi di Muaragembong

\section{Analisis Dampak Perubahan Fungsi Ekosistem Pesisir terhadap Lingkungan}

Sejalan dengan peningkatan jumlah penduduk di wilayah pesisir Kecamatan Muaragembong mengakibatkan kebutuhan masyarakat sekitar yang lebih memilih transportasi laut atau sungai untuk sampai ke pusat kota. Kondisi sungai yang cukup lebar, dengan lebar rata-rata antara 30-80 meter dan arus yang lemah serta kedalaman rata-rata sungai 3 meter menyebabkan sungai - sungai di Muaragembong menjadi prasarana transportasi utama bagi penduduknya. Selain eretan juga terdapat perahu yang melayani masyarakat sekitar sebagai transportasi umum dari Muara Tawar Cilincing ke Muaragembong (lihat Gambar 3)

ruang untuk permukiman, lahan untuk pengembangan kegiatan ekonomi masyarakat, sarana dan prasarana pendukung kehidupan penduduk juga meningkat. Ruang yang digunakan oleh masyarakat untuk memenuhi kehidupannya pada umumnya 
adalah pembukaan lahan dari kawasan ekosistem mangrove dan memanfaatkan lahan pada kawasan muara sungai (estuaria). Hal ini dimanfaatkan untuk pengembangan kegiatan permukiman, tambak dan sarana ekonomi yang mendukung pada kegiatan perikanan tangkap. Hal ini mengakibatkan terjadinya pengurangan luas mangrove dan perubahan penggunaan pada kawasan muara sungai (estuaria), sehingga mengakibatkan

Pengurangan luas mangrove mengakibatkan kondisi ekosistem mangrove di Wilayah Pesisir Muaragembong berkurang, sehigga terjadi perubahan fungsi dari ekosistem mangrove dari fungsi ekologis menjadi fungsi ekonomis untuk memenuhi kebutuhan hidup masyarakat. Hal ini mengakibatkan berkurangnya fungsi ekologis dari ekosistem mangrove yaitu sebagai pelindung pantai dari abrasi, pengendali banjir, tempat hidup biota laut untuk berlindung, mencari makan, pemijahan maupun pengasuhan, sebagai sumber makanan bagi spesies-spesies yang ada, penambat zat beracun, penyerap karbon. Hal ini memberikan dampak terhadap kondisi lingkungan di Wilayah Pesisisr Muaragembong.

Dampak yang ditimbulkan dari perubahan fungsi dari ekosistem mangrove ini di Wilayah Pesisir Muaragembong terhadap lingkungan adalah terjadinya abrasi dan banjir. Abrasi yang terjadi di Wilayah pesisir Muaragembong sudah terjadi perubahan garis pantai sampai lebih kurang sejauh $4 \mathrm{~km}$ (hasil wawancara). Sedangkan banjir yang terjadi di Wilayah Pesisir Muaragembong saat ini berasal dari gelombang pasang dan dari Sungai Citarum. Kedua hal ini mengakibatkan kerugian kepada masyarakat. Kerugian yang diderita oleh masyarakat Wilayah pesisir Muaragembong adalah rusaknya rumah, rusaknya jaringan jalan, berkurangnya jumlah produksi penangkapan ikan, sanitasi lingkungan permukiman jadi kurang baik, berkurangnya produksi dari udang, kepiting, kerang, tidak bisanya dimanfaatkan kawasan tersebut sebagai tempat rekreasi karena lingkungannya tidak mendukung untuk pengembangan kegiatan wisata saat ini. Hal ini mengakibat kerugian secara ekonomi terhadap masyarakat yang tinggal di Wilayah Pesisir Muaragembong. Hal ini dapat dilihat tidak terjadinya keseimbangan antara ketersediaan sumberdaya alam dengan tingkat pendapatan masyarakat. Wilayah Pesisir Muaragembong kaya akan sumberdaya alam yang mempunyai nilai ekonomi tinggi, sedangkan tingkat pendapatan masyarakat rata-rata adalah $\mathrm{Rp}$. 750.000,- - Rp. 1.000.000,- per bulan (hasil wawancara). Pendapatan yang dihasilkan oleh masyarakat di wilayah Pesisir Muaragembong ini masih berada di bawah UMR Kabupaten Bekasi yaitu Rp.2.447.445.000,- per bulan. Hal ini menunjukkan bahwa banyak dari masyarakat di Wilayah Pesisir Muaragembong pada kondisi pra sejahtera.

\section{KESIMPULAN}

Wilayah pesisir mempunyai arti strategis baik secara ekologi, ekonomi, dan sosial. Pemanfaatan sumberdaya alam yang terdapat di wilayah pesisisr yang tidak memperhatikan kesimbangan lingkungan, akan memberikan ekesternalitas negatif terhadap lingkungan dan kondisi sosial masyarakat. Eksternalitas negatif dari pemanfaatan sumbardaya alam di wilayah pesisisr yang tidak memperhatikan kaidah kesimbangan lingkungan di Wilayah pesisisr Muaragembong adalah terjadinya abrasi dan banjir yang mengakibatkan kerugian terhadap masyarakat. Disamping itu juga mengakibatkan berkurangnya jumlah produksi hasil usaha masyarakat. Hal ini merupakan salah satu indikator yang menyebabkan tingkat pendapatan masyarakat berada dibawah UMR yang ditetapkan.

\section{DAFTAR PUSTAKA}

Anonim. 2007c. Undang-undang Nomor 27 tahun 2007, tentang Pengelolaan Wilayah Pesisir dan Pulau-pulau Kecil 
. 2009. Rencana Tata Ruang Wilayah Kabupaten Bekasi tahun 2009 - 2029. Bappeda Kabupaten Bekasi.

. 2011. Laporan Tahunan Dinas

Peternakan, Perikanan dan

Kelautan. Dinas Peternakan,

Perikanan dan Kelautan: Kabupaten

Bekasi.

Asyiawati. 2010. Analisis Status Ekosistem

Pesisir bagi Penyusunan Rencana

Tata Ruang Wilayah Pesisir di

Kawasan Teluk Kota Ambon :

Disertasi. Institut Pertanian Bogor

Barus, T.A. 2002. Pengantar Limnologi.

Medan: Universitas Sumatra Utara.

Bengen DG. 2000a. Pengenalan dan Pengelolaan Ekosistem Mangrove.

Bogor : Pusat Kajian Sumberdaya Pesisr dan Laut, Institut Pertanian Bogor.

. 2000b. Teknik Pengambilan

Contoh dan Analisis Data Biofisik

Sumberdaya Pesisir. Bogor : Pusat

Kajian Sumberdaya Pesisir dan Laut

Fakultas Perikanan dan Ilmu

Kelautan, Institut Pertanian Bogor. . 2004. Ekosistem dan Sumberdaya

Alam Pesisir dan Laut serta Prinsip

Pengelolaannya. Bogor : Pusat

Kajian Sumberdaya Pesisir dan

Laut, Institut Pertanian Bogor.

2004. Pedoman Teknis:

Pengenalan dan Pengelolaan

Ekosistem Mangrove. Bogor : Pusat

Kajian Sumberdaya Pesisir dan

Laut, Institut Pertanian Bogor.

Brandon K. 1996. Ecotourism and Conservation : A Review of Key Issues, Global Environment Division

Chua TE. 2006. The Dynamic of Integrated Coastal Management : Practical Applications in the Sustainable Coastal Development in East Asia. Global Environment Facility/UNDP/PEMSEA. Quezone City. 468 p.
Clark JR. 1996. Coastal Zone Management : Handbook. United States of America : Lewis Publishers.

Dahuri R, Rais J, Sitepu MJ. 1996. Pengelolaan Sumberdaya Wilayah Pesisir dan Lautan Secara Terpadu. Jakarta : Pradnya Paramita.

Handayani. S. 2006. Kajian Perubahan Penggunaan Lahan di pesisir Muaragembong, Bekasi dengan Menggunakan Citra Landsat 7ETM+ : Skripsi. Institut Pertanian Bogor.

Fauzi A. 2008. Valuing Socio-economic benefit of protected area for human well-being. Report, Submitted to The Nature Conservancy (TNC) 2006. Ekonomi Sumber Daya Alam dan Lingkungan: Teori dan Aplikasi. Gramedia Pustaka Utama.

Forestian. O. 2011. Estimasi Biomassa dan Kerapatan Vegetasi Mangrove Menggunakan Data Landsat ETM+ (studi di Hutan Lindung dan Hutan produksi tetap Muaragembong, kabupaten Bekasi Provinsi Jawa barat) : Skripsi. Institut Pertanian Bogor.

Kay, R, Alder. J. 1999. Coastal Management and Planning. New York : E \& FN SPON.

Koesoebiono. 1995. Ekologi Wilayah Pesisir, Makalah Disampaikan Pada Pelatihan ICZPM Angkatan I. Bogor. September : 1995. 